\title{
Analisis Perkembangan Fasies Dan Lingkungan Pengendapan Pada Interval Formasi Kujung Dan Tuban, Blok West Tuban, Cekungan Jawa Timur
}

\author{
Anisa Nevi Saerina ${ }^{1}$, Anis Kurniasih $^{1}$, Reddy Setyawan ${ }^{1 *}$ \\ ${ }^{1}$ Departemen Teknik Geologi, Fakultas Teknik, Universitas Doponegoro
}

\begin{abstract}
Abstrak
Cekungan Jawa Timur merupakan cekungan hidrokarbon yang telah terbukti menghasilkan minyak bumi dengan reservoir utama yaitu pada Formasi Kujung dan Tuban. Tujuan penelitian ini adalah mengetahui variasi litologi, distribusi litologi secara lateral, fasies dan lingkungan pengendapan berdasarkan asosiasi litologi serta perkembangan terumbu yang berkaitan dengan perubahan muka air laut. Metode yang digunakan dalam penelitian ini adalah analisis kualitatif menggunakan data sumur berupa wireline log. Analisis kualitatif menggunakan software Paradigm Geolog 7.0 untuk mendeterminasi litologi. Selanjutnya, menganalisis dan membuat permodelan fasies, lingkungan pengendapan dan sikuen stratigrafi. Berdasarkan hasil analisis Formasi Kujung dan Tuban terdiri dari 4 jenis litologi, yaitu batugamping, batulempung, batulanau dan batupasir. Setelah dilakukan analisis fasies, formasi tersebut terdiri dari 4 fasies yaitu patch reef core, patch reefflank, off-mound near reef dan off-mound. Patch reef pada daerah penelitian dicirikan dengan litologi batugamping energi rendah diendapkan pada bagian rongga antar koloni terumbu, menghasilkan asosiasi skeletal wackestonepackstone. Lingkungan pengendapan terumbu berada pada platform terisolasi akibat segmentasi basement berarah timurlaut-baratdaya. Perubahan muka air laut Formasi Kujung dibagi menjadi yaitu TST-1 dan HST-1, kemudian dilanjutkan dengan TST-2 saat pengendapan Formasi Tuban. Fase transgresi awal terumbu tumbuh dengan fase catch up, pada fase high stand terumbu tumbuh dengan fase keep up dan pada saat transgresi kedua terumbu sebagian tetap berkembang sebagai keep up dan sebagian lainnya mengalami give up.
\end{abstract}

Kata kunci: Cekungan Jawa Timur; Formasi Kujung; Formasi Tuban; patch reef; platform terisolasi.

\begin{abstract}
The East Java Basin is a hydrocarbon basin that has been proven to produce petroleum with the main reservoir in the Kujung and Tuban Formations. This research aimed to determine the variation of lithology, lateral distribution of lithology, facies and depositional environment based on lithological associations and reef developments related to changes in sea level. The method used in this research is qualitative analysis using well data in the form of wireline logs. Qualitative analysis used Paradigm Geolog 7.0 Software to determine lithology. The next step is to analyze and make facies modeling, depositional environment and stratigraphic sequence. Based on the results of the analysis, the Kujung and Tuban Formations consist of 4 types of lithology, which is limestone, claystone, siltstone and sandstone. After analyzing the facies, the formation consists of 4 facies, namely patch reef Core, patch reef flank, off-mound near reef and off-mound. The patch reef in the study area is characterized by low energy limestone lithology deposited in the cavities between coral colonies, resulting in a skeletal wackestone - packstone association. The reef environment is located on an isolated platform due to the basement segmentation trending northeast - southwest. Changes in sea level in Kujung Formation were divided into TST-1 and HST-1, then continued with TST-2 during the deposition of Tuban Formation. In the early transgression phase, the reefs grew with a catch up phase, in the high stand phase the reefs grew with a keep up phase and at the time of the second transgression some reefs continued to develop as a keep up and others experienced give up.
\end{abstract}

Keywords: East Java Basin; Kujung Formation; Tuban Formation; patch reef; isolated platform.

\footnotetext{
* Korespondensi: reddysetyawan.23@gmail.com
}

Diajukan : 2 Februari 2021

Diterima : 16 Maret 2021

Diterbitkan : 31 Maret 2021 


\section{PENDAHULUAN}

Berdasarkan kajian petroleum system Cekungan Jawa Timur, batuan karbonat yang berkembang pada Oligo-Miosen berperan penting dalam sistem minyak bumi sebagai penyimpan hidrokarbon. Dalam tatanan stratigrafi, batuan karbonat tersebut tergolong dalam Formasi Kujung dan Tuban, Selama Oligo-Miosen, Cepu - Surabaya - Madura merupakan laut lepas (Satyana dan Purwaningsih, 2003). Cekungan ini dikelompokkan sebagai back-arc basin yang berjarak 75-150 km dari busur vulkanik OligoMiosen di selatan Jawa dan berada pada batas tenggara lempeng Eurasia (Mudjiono dan Pireno, 2002).

Menurut Satyana dan Djumlati (2003), Formasi Kujung dibagi menjadi 3 unit secara berurutan yang paling tua yaitu Kujung III yang terdiri dari material klastik atau clastic-rich, Kujung II berisi batuan karbonat sikuen transgresi laut dangkal dan shale serta terdapat karbonat build ups secara lokal pada daerah tinggian, Kujung I (Anggota Prupuh) terdiri dari batuan karbonat hasil endapan energi tinggi yang menghasilkan clean limestone dan umumnya berkembang build ups berupa pinnacle reef.

Terdapat 2 model pengendapan batuan karbonat Oligo-Miosen menurut Satyana dan Djumlati (2003) yaitu pengendapan pada platform yang menempel di darat (land-attached platform) dan pada platform yang terisolasi (isolated platform). Oleh karena sistem pertumbuhan terumbu yang tidak tersebar secara homogen, maka persebaran batugamping Formasi Kujung dan Tuban memiliki fasies yang beragam sesuai dengan lokasi pengendapannya. Pada beberapa fasies mampu menghasilkan batugamping dengan porositas dan permeabilitas yang baik dalam menyimpan hidrokarbon, maka analisis ini dapat membantu dalam menentukan zona-zona yang memungkinkan terakumulasinya hidrokarbon.

Djuhaeni dan Nugroho (2002) menunjukkan evolusi sedimentasi yang teramati di dalam endapan Tersier, dari Formasi Kujung hingga Formasi Lidah, memperlihatkan suatu keterkaitan antara pasokan sedimen, tektonik lokal dan fluktuasi paras air-laut relatif atau transgresi - regresi.

Purwaningsih (2002) melakukan analisis sikuen stratigrafi melalui seismik berdasarkan tektonik dan eustasi untuk mengidentifikasi pengendapan sikuen karbonat. Pada Akhir Oligosen karbonat Kujung berkembang di bagian barat tinggian Cepu Tmur yang terbagi menjadi 4 sikuen terdiri dari fase transgresi dan high stand.

Satyana (2002) membahas batuan karbonat yang tumbuh pada Oligo-Miosen terdiri dari Kujung, Prupuh, Tuban dan Rancak yang memiliki akumulasi hidrokarbon besar. Karbonat ini memiliki 2 model sedimentasi yaitu land-attached platform (saat ini offshore Jawa Timur) dan isolated platform (saat ini onshore Jawa Timur).

Sharaf dkk. (2005) menjelaskan mengenai fasies, persebaran fasies dan evolusi stratigrafi dari batuan karbonat dan sedimen silisiklastik Formasi Kujung, Tuban dan Ngrayong selama Oligosen hingga Miosen melalui data permukaan maupun data bawah permukaan. Fasies yang ditemukan pada daerah penelitian dibagi menjadi 2 yaitu fasies mound yang berisi batuan karbonat dan off-mound yang terdiri dari litologi batuan karbonat namun didominasi oleh material silisiklastik.

Berdasarkan uraian di atas, ini menjadi suatu hal yang mendasari penulis untuk melakukan kajian terhadap formasi yang menjadi target eksplorasi pada Cekungan Jawa Timur yaitu Formasi Tuban dan Kujung serta bagaimana susunan fasies dan lingkungan pengendapannya. Kajian ini didasarkan pada analisis kualitatif hasil pengeboran pada lapangan-lapangan Blok West Tuban yang dilakukan oleh JOB Pertamina - PetroChina East Java.

Tujuan penelitian antara lain mengetahui variasi litologi secara vertikal dari determinasi wireline log, mengetahui persebaran litologi secara lateral melalui korelasi stratigrafi, mengetahui persebaran fasies dan lingkungan pengendapan, serta mengetahui proses perkembangan karbonat yang berkaitan dengan fluktuasi muka air laut. Dengan dilakukannya analisis fasies, lingkungan pengendapan dan sikuen stratigrafi Formasi Kujung dan Tuban, diharapkan dapat memberikan hasil dan gambaran yang lebih baik untuk melihat potensi pengembangan lapangan lebih lanjut..

\section{METODOLOGI}

Penelitian menggunakan sampel berupa data wireline log yang dihasilkan dari uji parameter 
fisik batuan saat pengeboran. Data berasal dari 7 sumur yaitu TULIP-1, PEONY-1, PEONY-2, LOTUS-2, ASTER-1, LILY-1 dan LILY-2. Masing-masing sumur memiliki data kedalaman (TVD) dan juga parameter yang diuji. Parameter fisik batuan yang diuji meliputi: gamma ray untuk mengetahui unsur radioaktif batuan, resistivitas batuan, neutron, densitas, dan photoelectric factor.

Metode analisis kualitatif dilakukan melalui data wireline log. Data tersebut merepresentasikan parameter fisik dari batuan, sehingga dapat mendeterminasi litologi secara vertikal dengan menggunakan Geolog 7.0. Selama penilitian, dilakukan tahapan-tahapan kerja antara lain:

1. Tahap pengumpulan data meliputi tahap pengumpulan data primer dan tahap pengumpulan data sekunder. Data yang digunakan dalam penelitian berupa data $\log$ (LAS) sumur, data dari final well report, data dari rock description report, dan data seismik. Data log yang digunakan meliputi kedalaman (TVD), log gamma ray $(G R), \log$ spontaneous potential, resistivity log, sonic log, density log dan neutron logs. Final Well Report berisi informasi detail mengenai sumur seperti lokasi, formasi apa saja yang ditemukan pada pengeboran, kedalaman sumur dan hasil analisis core atau side wall core serta analisis laboratorium. Laporan rock description memuat informasi hasil analisis batuan inti, diantaranya adalah foto batuan inti, deskripsi litologi dan analisis petrografi dari sampel batuan sumur PEONY-2 dan analisis petrografi dari sampel sumur PEONY-1.

2. Tahap pengolahan data meliputi tahap analisis kualitatif data wireline $\log$, interpretasi litologi, korelasi stratigrafi, fasies dan lingkungan pengendapan.

3. Tahap evaluasi batuan inti. Tahap analisis batuan inti dilakukan melalui evaluasi well bore data dalam Final Well Report dan Rock Description Report. Hal ini bertujuan untuk mengetahui informasi secara rinci dan akurat pada hasil coring. Setelah mendapatkan data batuan inti maka tahap selanjutnya diteliti berdasarkan jenis fosil dan tekstur batuan

4. Tahap permodelan persebaran fasies dan lingkungan pengendapan serta perkembangan terumbu. Pada tahap ini dilakukan dengan membuat permodelan Formasi Kujung dan
Tuban untuk mengetahui permodelan fasies dan perkembangan terumbu serta proses pengendapan sedimen. Permodelan dari fasies ini menggabungkan dari hasil interpretasi well log dan seismik Formasi Kujung dan Tuban.

\section{HASIL}

Analisis data wireline log menghasilkan interpretasi litologi pada masing-masing sumur sebagai berikut:

\section{Sumur TULIP-1}

Sumur TULIP-1 terdiri dari 2 formasi dengan total ketebalan 2.740 kaki. Berdasarkan hasil analisis kualitatif pada Formasi Tuban dan Kujung terdiri dari 4 jenis litologi yaitu batulempung, batupasir, batulanau dan batugamping. Formasi Tuban terdiri dari litologi batulempung, batulanau, batupasir dan batugamping. Litologi yang paling sering dijumpai pada formasi ini adalah batulempung, sedangkan litologi lainnya berupa lapisan yang cukup tipis. Batugamping hanya dijumpai pada kedalaman 7.032 kaki berupa lapisan tipis.

Formasi Kujung terdiri dari litologi batulempung, batulanau, batupasir dan batugamping. Litologi yang mendominasi formasi ini adalah batulempung, sedangkan batugamping dijumpai di kedalaman 8.550 kaki hingga 8.750 kaki.

\section{Sumur PEONY-1}

Sumur PEONY-1 dengan top Formasi Tuban pada kedalaman 6.290 kaki hingga total depth pemboran, sehingga total ketebalannya adalah 1.260 kaki. Formasi Kujung tidak tertembus pada sumur ini. Berdasarkan hasil interpretasi well log pada Formasi Tuban terdiri dari litologi batugamping sebagai litologi yang mendominasi dan terdapat lapisan-lapisan tipis batulanau. Dari well log tersebut batulempung hanya berupa lapisan-lapisan tipis diantara batugamping yaitu pada kedalaman 6.693 hingga 7.370 kaki.

\section{Sumur PEONY-2}

Sumur PEONY-2 dengan top Formasi Tuban pada kedalaman 5.903 kaki hingga total depth pemboran, sedangkan Formasi Kujung tidak tertembus pada sumur ini, sehingga total ketebalannya adalah 1.026 kaki. Berdasarkan hasil interpretasi well log pada Formasi Tuban terdiri dari 3 jenis litologi yaitu batulempung, batulanau dan batugamping. Secara megaskopis pada Formasi Tuban terdapat litologi 
batulempung dengan ciri ditemukan fosil hasil rework dalam fragmen dan secara umum bersifat calcareous. Batugamping terdiri dari 5 jenis yaitu wackestone, rudstone, bindstone, packstone dan wackestone or packstone. Wackestone terdiri dari skeletal grain, dengan matriks berupa $m u d$, sering dijumpai komponen foraminifera besar, nodul dan intraklast di dalamnya. Litologi ini tersebar di kedalaman 6.810,0 hingga 6.832,4 kaki kecuali pada kedalaman $6.820,3$ sampai $6.823,8$ kaki berupa rudstone. Rudstone pada kedalaman ini memiliki komposisi koral. Packstone or wackestone ditemukan pada kedalaman 6.832,4 sampai $6.842,3$ kaki terdiri dari skeletal grain dan ditemukan fragmen coralline-alga. Bindstone memiliki ciri komposisi utama coralline-alga, ditemukan pada kedalaman 6.842,3 sampai 6.865,0 kaki. Packstone memiliki karakteristik litologi terdiri dari komponen skeletal, kadang terdapat intraklast, fragmen koral dan nodul, litologi ini dijumpai pada kedalaman 6.865,0 $6.908,3$ kaki. Wackestone kembali ditemukan pada kedalaman 6.886,8 sampai 6.928,4 kaki.

\section{Sumur LOTUS-2}

Sumur LOTUS-2 dengan top Formasi Tuban pada kedalaman -8.280 kaki hingga total depth pemboran, sehingga total ketebalannya adalah 513 kaki. Formasi Kujung tidak tertembus pada sumur ini. Formasi Tuban terdiri dari litologi batugamping yang mendominasi pada kedalaman lebih dari 8.452 kaki, sedangkan pada bagian atas batugamping didominasi oleh litologi batulempung dengan sisipan lapisan batulanau. Batulanau ditemukan pada kedalaman 8.428 kaki berupa lapisan tipis.

\section{Sumur ASTER-1}

Sumur ASTER-1 dengan top Formasi Tuban berada pada permukaan, base Tuban pada kedalaman 1.364 kaki, sedangkan base Formasi Kujung berada pada kedalaman 4.340 kaki. Formasi Tuban terdiri dari 4 jenis litologi dan litologi yang paling sering ditemukan pada formasi ini adalah batulempung. Batugamping ditemukan pada kedalaman lebih dari 4.565 kaki. Pola litologi dari formasi ini dari bagian bawah formasi hingga kedalaman 2.025 kaki mengalami pola menghalus ke atas, kemudian pada kedalaman 2.025 hingga top Formasi mengalami pola mengkasar. Formasi Kujung terdiri dari litologi batulempung, batulanau, batupasir dan batugamping yang dominan.

\section{Sumur LILY-1}

Sumur LILY-1 terdapat Formasi Kujung dan Tuban dengan total ketebalannya adalah 3.543 kaki. Formasi Tuban terdiri dari litologi batulempung, batulanau, batupasir dan batugamping dengan litologi yang paling dominan adalah batulempung. Batugamping ditemukan sebagai lapisan yang cukup tebal 5 sampai 50 kaki di kedalaman 111 sampai 2.272 kaki karena pada bagian base Tuban batugamping mengalami penebalan.

Formasi Kujung terdiri dari litologi batugamping, batulempung dan batulanau dengan litologi yang dominan adalah batugamping. Pada formasi tersebut batulempung dan batulanau berupa lapisan tipis di kedalaman 3.300 kaki.

\section{Sumur LILY-2}

Sumur ini terdiri dari 2 formasi, total ketebalannya adalah 3.750 kaki. Formasi Tuban menunjukkan litologi yang paling dominan adalah batulempung. Pada bagian atas formasi batulempung dominan dengan lapisan-lapisan batulanau, batupasir. Pada kedalaman lebih dari 1890 kaki batulempung dominan ditemukan dengan sisipan batugamping. Batulanau dan batupasir berupa lapisan tipis 5 - 25 kaki di kedalaman 970 hingga 1.009 kaki.

Formasi Kujung terdiri dari litologi batugamping, batulempung, batulanau dan batupasir. Batugamping mendominasi formasi ini. Batulempung ditemukan menyisip pada batugamping pada kedalaman 2.200 hingga 3.296 kaki. Batupasir ditemukan setempat. Batulanau ditemukan pada kedalaman lebih dari 2.100 kaki berupa lapisan tipis.

\section{PEMBAHASAN}

Mofologi pertumbuhan terumbu dengan persebaran yang terbatas atau patchy, maka tergolong skeletal frame-built reef berupa patch reef. Patch reef tersebut membentuk koloni terumbu pada area tinggian platform menghasilkan reef mound. Fasies yang ditemukan di daerah penelitian antara lain:

\section{Fasies core-patch reef}

Core-patch reef merupakan kelompok endapan yang berada pada inti patch reef. Fasies inti ini terdiri dari litologi berupa skeletal wackestone - packstone, kadang packstone mengalami gradasi menjadi grainstone dan bindstone, yang ditemukan di sumur PEONY-2. 
Litologi tersebut mengindikasikan bahwa energi pengendapan pada fasies core ini tergolong rendah sampai energi tinggi. Secara umum pada bagian inti fasies ini tidak banyak terdiri dari terumbu masif, karena letak pengendapan pada bagian interior patch reef yang memiliki banyak rongga atau cavities dan juga biasanya activegrowth-coral hanya akan tumbuh di bagian yang memiliki energi tinggi, sehingga pada bagian reef tersebut akan lebih tenang dan memiliki energi yang rendah (Gambar 1).

\section{Fasies flank-patch reef}

Endapan flank dicirikan dengan endapan seperti batulempung yang berasosiasi dengan batupasir dan batugamping klastik. Batugamping yang ditemukan di fasies ini masih dominan dibandingkan dengan material klastik, yang mencirikan wilayahnya masih sangat dekat dengan reef core (Gambar 1). Batugamping pada fasies ini memiliki komponen berupa detrital coral yang mencirikan fasies flank terpengaruh oleh produksi skeletal yang ada di inti namun mengalami resedimentasi.

\section{Fasies off-mound near reef}

Fasies ini memiliki distribusi luas yang saling berhubungan antar sumur dan memiliki hubungan menjari dengan endapan patch reef (Gambar 2). Endapan off-mound near reef ini berasosiasi dengan batupasir dengan sortasi yang buruk hingga baik yang mencirikan adanya mekanisme gravitasi yang terjadi saat pengendapkan, sehingga menghasilkan endapan debris dan turbidite. Endapan debris dan turbidite sangat terpengaruh oleh adanya slope.

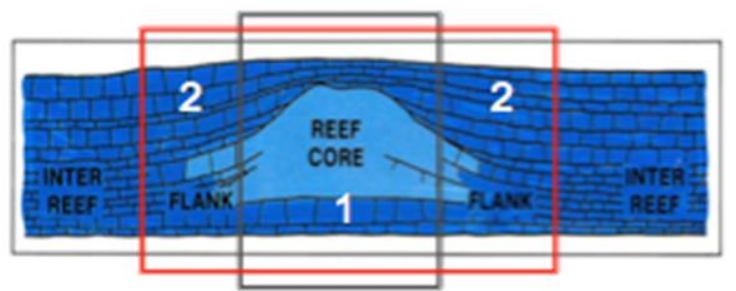

Gambar 1. Fasies Pengendapan pada Patch reef (James, 1979). Kotak abu-abu (nomor 1) adalah fasies Core-patch reef. Kotak merah (nomor 2) adalah fasies flank-patch reef.

\section{Fasies off-mound}

Fasies ini saling menjari dengan endapan offmound near reef. Pada fasies ini dicirikan dengan adanya endapan batulempung yang dominan. Endapan off-mound yang dominan pada material silisiklastik halus seperti batulempung dan sisipan batulanau dipengaruhi karena wilayahnya yang semakin jauh dan tidak terkena pengaruh terumbu, sehingga litologi yang ditemukan lebih halus dan tersortasi lebih baik dibandingkan dengan wilayah di dekat slope. Sistem pengendapan material silisiklastik dipengaruhi oleh gravitasi, sehingga menghasilkan endapan sistem turbidit, namun tidak ditemukan endapan debris. Batugamping yang tidak dominan mencirikan bahwa material batugamping sudah tidak menjadi suplai utama di wilayah pengendapan tersebut. Fasies offmound berkembang pada bagian interior platform (Gambar 2).

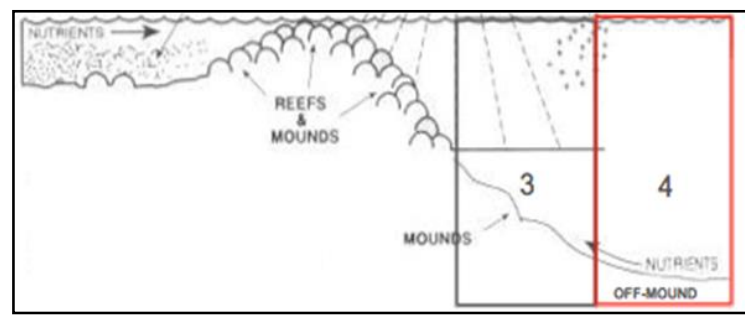

Gambar 2. Fasies Off-mound near reef (nomor 3) dan off-mound (nomor 4) (Tucker dan Wright, 1992).

Lingkungan pengendapan daerah penelitian dipengaruhi oleh struktur yang menghasilkan daerah tinggian menjadi lingkungan pengendapan batuan karbonat Di bagian graben menjadi tempat pengendapan batuan sedimen diwilayah slope dan basin. Daerah penelitian berada di East Cepu High, pada wilayah tersebut menjadi lingkungan pengendapan karbonat pada tinggian yang terisolasi atau isolated platform. Berdasarkan fasies yang ditemukan di daerah penelitian maka diinterpretasikan keseluruhan fasies berkembang pada lingkungan interior platform yang diinisiasi oleh mud-mound atau adanya tinggian lokal.

Berdasarkan analisis pola elektrofasies terdapat 3 sikuen pada Formasi Tuban dan Kujung yaitu TST-1, HST-1 dan TST 2. Pada awal pengendapan Formasi Kujung terdapat pengendapan dua jenis litologi berbeda yang berkembang. Jenis litologi pertama berupa batugamping yang dijumpai pada base Formasi Kujung sumur ASTER-1 dan TULIP-1. Pada bagian bawah Formasi Kujung masih dijumpai banyak batulempung, sehingga konfigurasi secara vertikal menunjukkan pola retrograding. Pola menghalus ke atas ini menggambarkan proses pengendapan dominan pada endapan 
energi rendah karena kenaikan muka air yang telatif cepat yaitu fase TST yang pertama.

Pada bagian tengah Formasi Kujung yang tergambar pada sumur ASTER-1, LILY-1 dan LILY-2 menunjukkan litologi yang dominan adalah batugamping. Pola elektrofasies cenderung simetris dan funnel shape di bagian paling atas batugamping. Karakter simetris cenderung dominan dimana pola elektrofasies memiliki pola litologi aggrading. Pola agradasi diinterpretasikan menghasilkan pertumbuhan terumbu yang mampu menyeimbangkan dengan kenaikan muka air laut, sehingga disebut sebagai fase catch up.

Pengendapan batugamping pada sumur ASTER-1, LILY-1 dan LILY-2 yaitu pada reefal yang kondisinya merupakan tinggian yang seimbang dengan permukaan air laut, sehingga mampu berkembang terumbu. Apabila terjadi kenaikan muka air laut dan diimbangi dengan pertumbuhan terumbu yang cepat makan akan terjadi fase keep up carbonate, hal ini juga didukung dengan morfologi pengendapan yang relatif tinggi. Terumbu mampu mengimbangi kenaikan muka air laut, sehingga terumbu dapat terus tumbuh hingga fasa akhir pengendapan. Sumur ASTER-1 setelah terjadi pertumbuhan terumbu mengalami fase muka air laut naik yang relatif cepat ditandai dengan diendapkannya batulempung di atas batugamping. Pada TULIP1 diinterpretasikan sejak awal pengendapan hingga akhir merupakan daerah yang dalam, sehingga yang diendapkan berupa endapan laut dalam berupa batulempung dari base hingga akhir pengendapan Formasi Kujung.

Pada awal pengendapan Formasi Tuban terdapat pengendapan dua jenis berupa batugamping yang dijumpai pada base Formasi Kujung sumur PEONY-1, PEONY-2 dan LOTUS-2. Pola elektrofasies cenderung simetris dan bell shape di bagian paling atas batugamping. Pengendapan batugamping pada reefal yang kondisinya merupakan tinggian yang masih seimbang dengan air laut, sehingga mampu berkembang terumbu disekitar daerah tersebut dan build-up berkembang hingga akhir pengendapan Formasi Tuban. Terumbu tersebut mampu mengimbangi kenaikan muka air laut, sehingga terumbu dapat terus tumbuh hingga fase akhir pengendapan.

Pada sumur TULIP-1, ASTER-1, LILY-1 dan LILY-2 menunjukan pengendapan dari awal hingga akhir Formasi Kujung didominasi oleh batulempung dengan sisipan batulanau, batupasir dan batugamping. Batulempung ini memiliki pola elektrofasies yang ditunjukkan

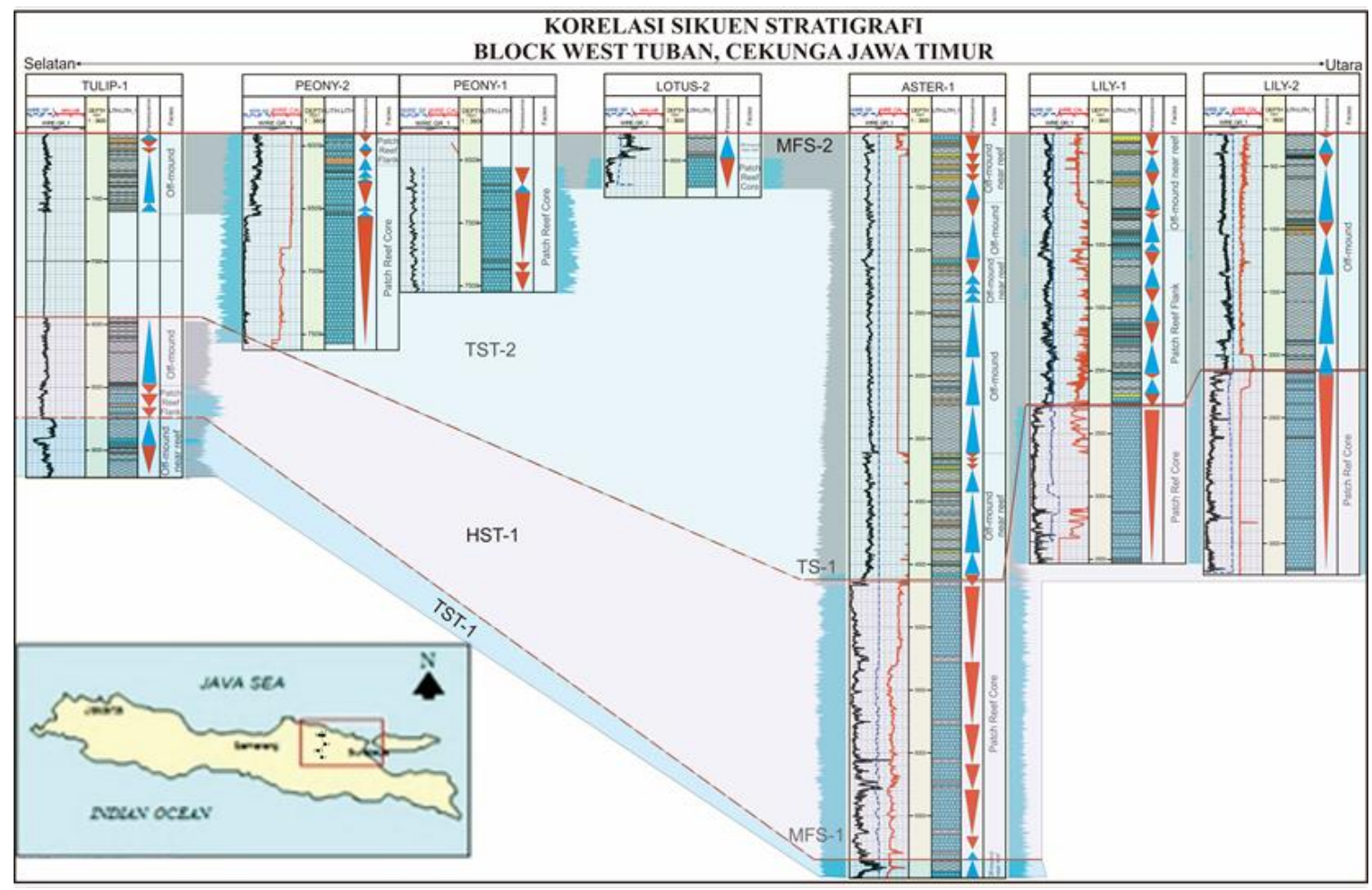

Gambar 3. Sikuen Stratigrafi Formasi Kujung dan Tuban. 


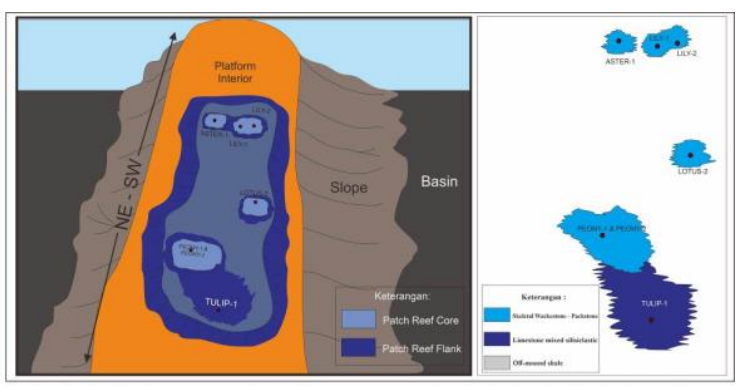

Gambar 4. Persebaran Fasies Formasi Kujung (Oligosen - Miosen).

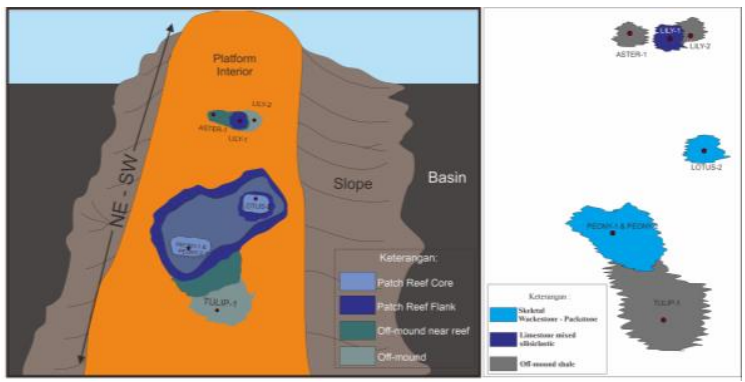

Gambar 5. Persebaran Fasies Formasi Tuban (Miosen Awal)

berupa bell shape menghasilkan pola backstepping pengendapan ke arah darat dengan pola retrogradasional diinterpretasikan sejak awal pengendapan hingga akhir merupakan daerah yang dalam, sehingga yang diendapkan berupa endapan laut dalam berupa batulempungdari base hingga akhir pengendapan Formasi Tuban.

Hasil korelasi stratigrafi dari selatan hingga utara daerah penelitian menunjukkan bahwa distribusi batugamping pada Formasi Kujung hanya secara setempat sebagai build-up carbonate. Hal ini menyebabkan pelamparannya tidak dapat dihubungkan secara lateral namun menerus secara vertikal, yang menyebabkan hubungan stratigrafi lateralnya berupa interfingering dengan litologi disekitarnya (Gambar 3).

Pada sumur TULIP-1, ASTER-1, LILY-1 dan LILY-2 diinterpretasikan wilayah pengendapan yang cenderung lebih rendah atau di wilayah slope yang masih relatif dekat dengan tinggian, sehingga ditemukan asosiasi batuan sedimen klastik halus yang terendapkan dengan mekanisme gravitasi. Sumur PEONY-1, PEONY-2, LOTUS-2 diperkirakan terendapkan pada zona paleo-high. Persebaran fasies dan litologi pada lingkungan pengendapan platform terisolasi dapat dilihat pada Gambar 4 dan Gambar 5.
Rekonstruksi perkembangan terumbu di lokasi penelitian dibuat berdasarkan penggabungan hasil interpretasi well $\log$ dan seismik Formasi Kujung dan Tuban. Perkembangan terumbu di daerah penelitian dimulai pada Oligosen setelah terjadinya segmentasi basement yang terjadi sebelum Eosen, yang menghasilkan morfologi pengendapan yang berbeda-beda. Pengendapan awal terjadi pada tengah - akhir Eosen yaitu Formasi Ngimbang yang terdeposisi sebelum tumbuhnya terumbu berupa material klastik di bagian relief rendah. Terjadi transgresi di laut selama Akhir Eosen - Awal Oligosen, terdapat endapan sedimen dangkal dan $\mathrm{CD}$ Limestone (Ngimbang Carbonate) mulai berkembang.

Setelah Tengah Oligosen terjadi uplift, terjadi transgresi pada cekungan selama Akhir Oligosen - Awal Miosen. Seiring dengan terjadinya transgresi Formasi Kujung terdeposisi selama periode tersebut. terbentuk endapan karbonat secara lokal di wilayah tinggian dan sedimen berukuran halus di wilayah yang lebih rendah. Proses kenaikan muka air laut tidak terlalu cepat, sehingga terumbu tumbuh dan menyebar secara lateral yang dikenal dengan fase catch up.

Pada Miosen proses transgresi masih terus terjadi, sehingga memicu perkembangan terumbu secara menerus dari Formasi Kujung yang sebelumnya terbentuk. Bentuk dari terumbu Tuban lebih tinggi dari terumbu yang dihasilkan Formasi Kujung, sebagai akibat dari proses transgresi yang terjadi lebih cepat daripada sebelumnya. Persebaran karbonat lebih sempit karena menyeimbangkan dengan kenaikan muka air laut, sehingga disebut dengan fase keep up. Akhir dari pertumbuhan terumbu (give up) berasosiasi dengan tenggelamnya platform dan burial oleh material klastik. Sedimen Formasi Ngrayong diendapkan selama Tengah Miosen. Endapan karbonat mengalami pengangkatan pada Neogen khususnya di wilayah utara yaitu pada sumur LILY-1, LILY-2 dan ASTER-1. Fase perkembangan terumbu dan kaitannya dengan perubahan muka air laut dapat dilihat pada Gambar 6 .

\section{KESIMPULAN}

Hasil analisis setiap sumur didapat kesimpulan sebagai berikut:

1. Berdasarkan hasil analisis kualitatif, pada Formasi Kujung litologi yang dominan 


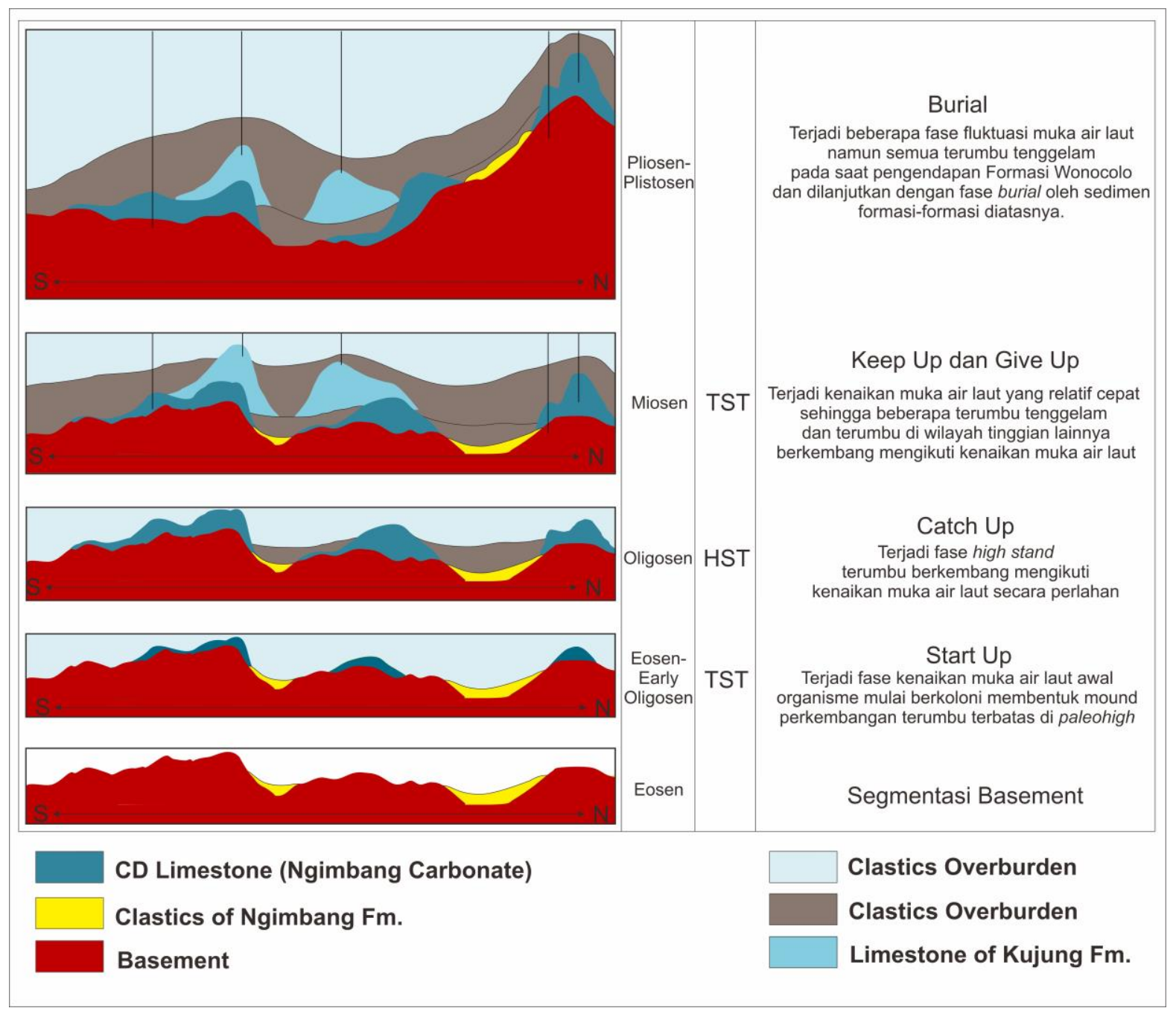

Gambar 6. Perkembangan Terumbu Formasi Kujung dan Tuban

adalah batugamping dengan sisipan batulempung pada bagian atas formasi, kecuali pada sumur TULIP-1 terdiri dari litologi batulempung. Formasi Tuban terdiri dari litologi dominan berupa batulempung, namun pada sumur PEONY-1 dan PEONY-2 Formasi Tuban berupa batugamping.

2. Hasil korelasi litostratigrafi menunjukkan batugamping ditemukan secara lokal dan memiliki hubungan saling menjari dengan endapan silisiklastik. Setelah dilakukan analisis fasies Formasi Kujung dan Tuban dibagi menjadi 4 fasies yaitu patch reef Core, patch reef flank, off-mound near reef dan offmound. Patch reef Core dicirikan dengan litologi yang dominan yaitu batugamping wackestone - packstone yang diendapkan pada bagian rongga diantara koloni terumbu, sehingga memiliki energi rendah. Patch reef flank terdiri dari asosiasi litologi batugamping, batupasir, batulanau dan batulempung, litologi tersebut diendapkan di zona slope depan terumbu, sehingga menghasilkan litologi campuran batulempung dan batugamping yang masih relatif tebal dengan sistem pengendapan dipengaruhi oleh gravitasi. Fasies off-mound near reef merupakan fasies yang didominasi dengan endapan silisiklastik namun masih mendapatkan suplai material dari terumbu disekitarnya. Semakin jauh dari zona terumbu dan slope memiliki litologi silisiklastik berkururan halus dengan mekanisme pengendapan debris dan turbidit dikelompokkan menjadi fasies off-mound.

3. Lingkungan pengendapan Formasi Kujung dan Tuban adalah isolated platform yaitu platform yang dikelilingi oleh rendahan yang dipengaruhi oleh segmentasi basement dengan arah timurlaut-baratdaya mengikuti 
Pola Meratus. Pada platform ini terumbu berkembang dalam bentuk patch reef pada interior platform.

4. Hasil analisis sikuen stratigrafi Formasi Kujung dibagi menjadi 2 fase fluktuasi yaitu TST-1 dan HST-1, fase TST-1 dijumpai pada awal pertumbuhan terumbu yang masih diselingi oleh batulempung di antara batugamping fase catch up pada daerah tinggian sebagai penciri adanya kenaikan muka air laut atau TS. Kemudian pada fase HST-1 dicirikan dengan stacking pattern mengkasar ke atas atau suksesi progradasi yang diinterpretasikan karena pertumbuhan terumbu mampu mengimbangi proses HST-1 menghasilkan fase keep up. Formasi Tuban mengalami 1 fase fluktuasi yaitu fase TST-2 yaitu kenaikan muka air laut yang dicirikan dengan banyaknya endapan batulempung menghasilkan pola menghalus ke atas. Hal ini melatar belakangi terjadinya fase give up terumbu pada sumur LOTUS-2, ASTER-1, LILY-1 dan LILY-2, sedangkan pada sumur PEONY-1 dan PEONY-2 yang masih berupa endapan terumbu fase keep up hal ini dikarenakan PEONY-1 dan PEONY-2 berada di paleo-high.

Dalam melakukan pengembangan lapangan Blok West Tuban berdasarkan studi fasies, maka zona reservoir yang baik di wilayah penelitian adalah bagian build-up carbonate. Pada build-up carbonate tersebut, fasies yang memiliki komponen yang paling baik dalam menyimpan hidrokarbon adalah fasies core patch reef. Asosiasi litologi yang ditemukan pada fasies tersebut adalah batugamping jenis wackestone, packstone, grainstone dan bindstone. Fasies core patch reef dapat ditemukan pada Formasi Tuban sumur PEONY-1, PEONY-2, serta Formasi Kujung pada sumur ASTER-1, LILY-1 dan LILY-2.

\section{UCAPAN TERIMA KASIH}

Menuliskan ucapan terima kasih, kepada JOB Pertamina-PetroChina East Java yang membantu dalam memberikan data untuk penelitian ini, juga reviewer yang telah bersedia melakukan review.

\section{DAFTAR PUSTAKA}

Djuhaeni dan Nugroho, D., 2002. Siklus Transgresi-Regresi dan Sedimentasi Tersier di Cekungan Jawa Timur Utara: Suatu Kajian Berdasarkan Stratigrafi Sikuen, Buletin Geologi, Vol. 34, No.3, hal.191-204.

James, N.P., 1979. Shallowing Upward Sequence in Carbonate, dalam Walker, R.G., ed., Facies Models : Respons to Sea Level Changes, Canada : Geological Association of Canada.

Mudjiono, R. dan Pireno, G. E., 2001. Exploration Of The North Madura Platform, Offshore East Java, Indonesia. Proceedings of Indonesian Petroleum Association 28th Annual Convention \& Exhibition.

Purwaningsih, M.E.M., Satyana, A.H., Budiyani, S., Noeradi, D., dan Halik, N.M., 2002. Evolution of The Late Oligosen Kujung Reef Complex in The Western East Cepu High, East Java Basin: Seismic Sequence Stratigraphy Study. Proceedings of 31th Annual Conference Indonesian Association of Geologist (IAGI).

Satyana, A.H., 2002. Oligo-Miocene Reefs: East Java's Giant Fields. Proceedings of Indonesian Association of Geologist (IAGI) Giant Field and New Exploration Concept Seminar.

Satyana, A.H. dan Djumlati, M., 2003. OligoMiocene Carbonate of The East Java Basin, Indonesia: Facies Definition Leading to Recent Significant Discoveries, Proceedings of American Association of Petroleum Geologist $(A A P G)$ International Conference.

Satyana, A.H. dan Purwaningsih, M.E.M., 2003. Oligo-Miocene Carbonates of Java : Tectonic Setting and Effect of Volcanism. Proceedings of Joint Convention Jakarta The 32th IAGI and 28th HAGI Annual Convention and Exhibition.

Sharaf, E., Simo, J.A., Carroll, A.R., Shields, M., 2005. Stratigraphy Evolution of OligoMiocene Carbonate and Siliciclastics, East Java Basin, Indonesia. American Association of Petroleum Geologist (AAPG) Bulletine, 89(6), hal.799-819.

Tucker, M. E. dan Wright, P., 1990. Carbonate Sedimentology. Oxford: Blackwell Scientific Publication. 